Check for updates

The BMJ

Cite this as: $B M / 2021 ; 374: n 1841$ http://dx.doi.org/10.1136/bmi.n1841 Published: 20 July 2021

\section{Covid-19: Vulnerable children aged 12-15 will be offered Pfizer vaccine, UK announces}

\author{
Elisabeth Mahase
}

Children aged 12-15 who are at increased risk of serious illness from infection with SARS-CoV-2 will be offered the Pfizer-BioNTech vaccine, the UK's Joint Committee on Vaccination and Immunisation (JCVI) has announced.

This will include children with severe neurodisabilities and those with underlying conditions that result in immunosuppression. The committee has also recommended that children aged 12-17 who live with an immunosuppressed person will also be offered the vaccine. This adds to the existing recommendation that at-risk young people aged 16-17 should be offered the vaccine.

The vaccine is not being recommended to children outside these groups, as the committee concluded that the "health benefits in this population are small, and the benefits to the wider population are highly uncertain.”

The Pfizer vaccine is the only covid-19 vaccine authorised for children (aged 12 and over) in the UK. Extremely rare reports of myocarditis and pericarditis have arisen after the Pfizer and Moderna vaccines were given to millions of younger adults. ${ }^{1}$

\section{Confusion}

Penelope Toff, co-chair of the BMA's Public Health Medicine Committee, expressed concern that adolescents living in multigenerational households and communities, particularly in more deprived areas, had been excluded from this list of eligible children. She said it was "vital" that they were considered.

Lawrence Young, virologist and professor of molecular oncology at Warwick Medical School, said that the decision not to offer the vaccine to all children aged 12 and over was "worrying," especially as England was now "relying on vaccination and personal responsibility, as opposed to mandated restrictions."

Covid-19 restrictions in England were eased on 19 July despite new cases rising to 50 ooo a day and experts warning that around half a million people could develop long covid during this wave of infections. ${ }^{2}$ Young highlighted other countries-including many in the EU, as well as Singapore, Japan, the UAE, the US, Canada, and the Philippines-where all children aged 12 and over were to be offered the vaccine. ${ }^{3}$

Penny Ward, visiting professor in pharmaceutical medicine at King's College, London, expressed confusion at the list of conditions considered to put children at risk of severe illness, ${ }^{4}$ as many of the conditions listed for 16-18 year olds were not included in the age $12-15$ list. ${ }^{5}$
She said, "No clear explanation is given for this, and as a consequence one might imagine lengthy discussions in GP surgeries between parents of children with brittle diabetes and renal disease and their GP adviser. Perhaps JCVI might consider a fuller-preferably completely referenced-document for use by the folks at the sharp end of patient care."

\section{Pregnancy}

When asked at a Science Media Centre briefing about vaccinating under 16 year olds who are pregnant, Adam Finn, JCVI member and a professor of paediatrics at the University of Bristol, said that it was a tricky decision but that the vaccine had not been recommended for this group.

He said, "We are now receiving increasing amounts of information that does indicate that pregnant women are not just similarly at risk, but actually probably an enhanced risk compared to other women of the same age. But balance of risk and benefit gets quite difficult when you get down into teenage pregnancies, because the risks of serious disease in teenagers get progressively lower as they get younger.

"So at the moment, pregnant under 16 year olds are not listed in our recommendations. But of course, that evidence will be kept under close review."

\section{Long covid}

Responding to concerns around long covid in children, Finn said that the current evidence suggested that the "likelihood of longlasting symptoms in children having had the infection beyond one to two months is extremely low."

However, other health leaders, including Taiwan's former director general of health promotion administration, Shu-Ti Chiou, have highlighted studies in children which have reported surprisingly high levels of long covid. One study of 129 children infected with the virus found that while only six were admitted to hospital, half of the children still reported at least one covid-19 symptom six months post-infection. 6

Wise J. Covid-19: Should we be worried about reports of myocarditis and pericarditis after mRNA vaccines?BMJ2021;373:n1635.

doi: 10.1136/bmj.n1635 pmid: 34167952

2 Mahase E. Covid-19: Experts condemn UK "freedom day" as dangerous and unethical. BMJ2021;374:n1829doi: 10.1136/bmj.n1829.

Mahase E. Covid vaccine could be rolled out to children by autumn. BMJ

$4 \quad$ Public Health England. Table 3: Clinical and other risk groups 16 years of age and over who should receive covid-19 immunisation. Available in: Covid-19: the green book, chapter 14a. Updated 1 Jul 2021. https://assets.publishing.service.gov.uk/government/uploads/system/uploads/attachment_data/file/998309/Greenbook_chapter_14a_1July2021.pdf. 2021;372:n723. doi: 10.1136/bmj.n723 pmid: 33727232 
5 Department of Health and Social Care. JCVI statement on covid-19 vaccination of children and young people aged 12 to 17 years: 15 July 2021. 19 Jul 2021. https://www.gov.uk/government/publications/covid-19-vaccination-of-children-and-young-people-aged-12-to-17-years-icvi-statement/ivci-statement-on-covid-19-vaccination-of-children-and-young-people-aged-12-to-17-years-15-july2021\#advice.

6 Buonsenso D, Munblit D, De Rose C, etal. Preliminary evidence on long COVID in children. Acta Paediatr 2021;110:2208-11. doi: 10.1111/apa.15870. pmid: 33835507

This article is made freely available for use in accordance with BMJ's website terms and conditions for the duration of the covid-19 pandemic or until otherwise determined by BMJ. You may use, download and print the article for any lawful, non-commercial purpose (including text and data mining) provided that all copyright notices and trade marks are retained. 